\title{
Ambient air pollution and birth defects in Haikou city, Hainan province
}

\author{
Zhijiang Liang ${ }^{1}$, Li Wu' ${ }^{1}$, Lichun Fan² and Qingguo Zhao ${ }^{1 *}$
}

\begin{abstract}
Background: Evidence shows exposure to ambient air pollution during pregnancy was associated with an increased risk of adverse birth outcomes, such as preterm birth, low birth weight and intrauterine growth retardation, but the results for birth defects have been inconsistent.

Methods: The data on birth defects was collected from the Birth Defects Monitoring Network of Haikou city. Air pollution data for $\mathrm{PM}_{10}, \mathrm{SO}_{2}$ and $\mathrm{NO}_{2}$ were obtained from Haikou Environmental Monitoring Center. Logistic regression analysis was used to evaluate these associations.

Results: The risk of birth defects was related to $\mathrm{PM}_{10}$ levels (adjusted $\mathrm{OR}=1.039 ; 95 \% \mathrm{Cl}=1.016-1.063$ ) and $\mathrm{SO}_{2}$ levels (adjusted $\mathrm{OR}=0.843 ; 95 \% \mathrm{Cl}=0.733-0.969$ ) for the second month of pregnancy. In the third month of pregnancy, the risk of birth defects was also related to PM10 levels (adjusted $\mathrm{OR}=1.066 ; 95 \% \mathrm{Cl}=1.043-1.090$ ) and $\mathrm{SO}_{2}$ levels (adjusted $\mathrm{OR}=0.740 ; 95 \% \mathrm{Cl}=0.645-0.850$ ).
\end{abstract}

Conclusion: The study provides evidence that exposure to $\mathrm{PM}_{10}$ and $\mathrm{SO}_{2}$ during the second and third month of pregnancy may associated with the risk of birth defects.

Keywords: Air pollution, Birth defects, $\mathrm{PM}_{10}, \mathrm{SO}_{2}, \mathrm{NO}_{2}$

\section{Background}

Air pollution has become a common problem in many countries. Air pollution not only contributes to global warming but also has deleterious effects on the human health [1]. Children and pregnant women are especially vulnerable to the adverse impacts of air pollution [2]. Recent epidemiologic studies in different countries have indicated that there is association between ambient air pollution and adverse birth outcomes, such as preterm birth, low birth weight and intrauterine growth retardation [3-7]. However, studies in which the associations between ambient air pollution and birth defects are limited, and the periods of gestation when ambient air pollution may be associated with birth defects is also unclear. Smrcka et al. found that living in areas with industrial pollution was association with higher rates of congenital anomalies [8]. The study conducted in Southern California showed that ambient $\mathrm{CO}$ was positively associated with an increased risk of ventricular

\footnotetext{
*Correspondence: 1693910767@qq.com

'Guangdong Women and Children Hospital, Guangzhou, China

Full list of author information is available at the end of the article
}

septal defects [9]. A recent study conducted in Brisbane found associations between $\mathrm{O}_{3}$ exposure and an increased risk of pulmonary artery and valve defects, and $\mathrm{SO}_{2}$ exposure and an increased risk of aortic artery and valve defects [10].

Birth defect is a part of a spectrum of adverse birth outcomes that may be associated with exposure to ambient air pollution. They have been a global public health issue, which are the main causes of early miscarriage, perinatal death and child disability. In China, the estimated prevalence is around $4 \%$ to $6 \%[11,12]$. Approximately a quarter of perinatal deaths are affected by birth defects either directly or indirectly [13]. The etiology of congenital anomalies is unknown for as many as $60 \%$ cases, but about $6-8 \%$ is associated with exposure to environmental factors [14]. The study of birth defects is an important emerging field of environmental epidemiology.

There is growing evidence suggesting that ambient air pollution during pregnancy is associated with congenital anomalies. However, there has been limited research on the effect of air pollution during critical periods of pregnancy on birth defects. Based on air pollution monitoring 
network and birth defects surveillance system, we investigated whether maternal exposure to air pollution was associated with elevated birth defect risk in infants delivered between 2009 and 2011 in Haikou city, Hainan province. And we explore the sensitive gestations during which air pollution affect birth defects most significantly. We focused on air pollutants such as sulfur dioxide $\left(\mathrm{SO}_{2}\right)$, nitrogen dioxide $\left(\mathrm{NO}_{2}\right)$, and particles with an aerodynamic diameter of $\leq 10 \mathrm{um}\left(\mathrm{PM}_{10}\right)$.

\section{Methods}

\section{Subjects}

The data on birth defects was collected from the Birth Defects Monitoring Network of Haikou city. The monitoring system is hospital-based registry, and the hospitals at the county level or above were selected to participate. The subjects monitored by the system included live births and stillbirths who were delivered in hospital after at least 28 weeks of gestation. The clinical diagnosis of birth defects was diagnosed within 7 days after delivery. Within this period, all diagnosed birth defects were required to be reported. We used unmatched case control study. Control infants were the other normal birth infants in this system. Control infants were selected from birth certificates, provided by the Haikou Department of Health Services. The data used in our study comprised all singleton births for the period of 1 January 2009 to 31 December 2011. During this period, there were 64100 singletons births included in our study. We received permission from Hainan Women and Children Hospital to use the data. The study was reviewed and approved by Guangdong Women and Children Hospital.

Information was collected from the birth certificates on gestation, birth weight, date of the last menstrual period (LMP), neonate gender, and age of mother.

\section{Exposure assessment}

For the period January 2009 to December 2011, air pollution data for $\mathrm{PM}_{10}, \mathrm{SO}_{2}$ and $\mathrm{NO}_{2}$ were obtained from Haikou Environmental Monitoring Center. Hourly readings were obtained for $\mathrm{PM}_{10}, \mathrm{SO}_{2}$ and $\mathrm{NO}_{2}$. A daily average was calculated for $\mathrm{PM}_{10}, \mathrm{SO}_{2}$ and $\mathrm{NO}_{2}$.

We calculated the exposure parameters from the monthly average concentrations for the duration of pregnancies from 2009 through 2011. We also calculated the average concentration over the days of gestation for first, second and third month of gestation as this is the critical period of gestation associated with birth defects [15].

\section{Statistical methods}

The effect of ambient air pollution on birth defects was estimated by logistic regression. We used odds ratio (OR) as a measure of the relation between exposure to air pollution and the risk of birth defects. We estimated adjusted OR using multiple logistic regression analysis and present the results as OR, along with 95\% confidence interval (95\% CI). We adjusted for risk factors that could potentially confound the relation between birth defects and air pollution. These factors were maternal age $(<20,20 \sim 24,25 \sim 29,30 \sim 34, \geq 35$ years), maternal race (Han, others), infant sex (male/female), birth weight $(<2500 / \geq 2500 \mathrm{~g})$, gestational age $(<37 / \geq 37$ weeks $)$. We could not consider alcohol, tobacco and drug use during pregnancy, because these data are not recorded in the Haikou birth certificates. Statistical analysis was conducted using SPSS for Windows version 13.0.

\section{Results}

\section{Characteristics of subjects}

Characteristics of infants with or without birth defects are presented in Table 1. A large proportion of birth defects than control was male $\left(\chi^{2}=3.70, P=0.05\right)$, shorter gestational age $\left(\chi^{2}=4118.32, P<0.01\right)$, low birth weight $\left(\chi^{2}=2521.36, P<0.01\right)$ and Han race $\left(\chi^{2}=15.22, P<0.01\right)$.

\section{Air pollution}

Descriptive statistics for air pollution levels during the study period are shown in Table 2. Levels of air pollutants had yearly variation. The levels of $\mathrm{NO}_{2}$ and $\mathrm{PM}_{10}$ showed no difference among three years $(P>0.05)$. The level of $\mathrm{SO}_{2}$ in 2011 was highest among three years, and there is difference among these years $(P<0.05)$.

\section{Air pollution and the risk of birth defects}

Table 3 shows the effect estimates from single-pollutant model. In the model, the risk of birth defects was related to $\mathrm{PM}_{10}$ levels, particularly in the third month of pregnancy $(\mathrm{OR}=1.012 ; 95 \% \mathrm{CI}=1.003-1.021)$.

Table 4 shows the effect estimates from three-pollutant model. In the three-pollutant models, the risk of birth defects was related to $\mathrm{PM}_{10}$ in the third month of gestation, after adjusting for other two air pollutants.

Table 5 summarizes the results of logistic regression analysis from each single pollutant model, adjusting for maternal age, maternal race, infant gender and birth weight. In the single-pollutant model, the adjusted OR for $\mathrm{PM}_{10}$ was $1.021(95 \% \mathrm{CI}=1.008-1.034)$ for the third month of pregnancy.

Table 6 summarizes the results of logistic regression analysis from three-pollutant models, adjusting for maternal age, maternal race, infant gender and birth weight. In the three-pollutant models, the risk of birth defects was related to $\mathrm{PM}_{10}$ levels (adjusted $\mathrm{OR}=1.039 ; 95 \%$ $\mathrm{CI}=1.016-1.063$ ) and $\mathrm{SO}_{2}$ levels (adjusted $\mathrm{OR}=0.843$; $95 \% \mathrm{CI}=0.733-0.969$ ) for the second month of pregnancy. In the third month of pregnancy, the risk of birth defects was also related to $\mathrm{PM}_{10}$ levels (adjusted OR $=1.066$; 95\% 
Table 1 Characteristics of subjects in Haikou city, Guangdong Province

\begin{tabular}{|c|c|c|c|c|}
\hline Characteristics & Cases, n (\%) & Controls, n (\%) & $x^{2}$ & $\mathbf{P}$ \\
\hline \multicolumn{5}{|l|}{ Infant sex } \\
\hline Male & $261(51.28 \%)$ & 35201 (55.53\%) & 3.70 & 0.05 \\
\hline Female & $248(48.72 \%)$ & $28190(44.47 \%)$ & & \\
\hline \multicolumn{5}{|c|}{ Maternal age (years) } \\
\hline$<20$ & $20(3.78 \%)$ & 2419 (3.81\%) & 21.75 & $<0.01$ \\
\hline $20 \sim 24$ & 109 (20.60\%) & $15786(24.85 \%)$ & & \\
\hline $25 \sim 29$ & 195 (36.86\%) & 24197 (38.09\%) & & \\
\hline $30 \sim 34$ & 110 (20.79\%) & 13707 (21.57\%) & & \\
\hline$\geq 35$ & 95 (17.96\%) & 7424 (11.69\%) & & \\
\hline \multicolumn{5}{|c|}{ Gestational age (weeks) } \\
\hline$<37$ & 419 (79.21\%) & 4217 (6.63\%) & 4118.32 & $<0.01$ \\
\hline$\geq 37$ & 110 (20.79\%) & $59354(93.37 \%)$ & & \\
\hline \multicolumn{5}{|l|}{ Birth weight(g) } \\
\hline$<2500$ & 327 (61.81\%) & $4070(6.40 \%)$ & 2521.36 & $<0.01$ \\
\hline$\geq 2500$ & $202(38.19 \%)$ & $59501(93.60 \%)$ & & \\
\hline \multicolumn{5}{|l|}{ Maternal race } \\
\hline Han & $516(97.54 \%)$ & 59307 93.29\%) & 15.22 & $<0.01$ \\
\hline Other & $13(2.46 \%)$ & $4264(6.71 \%)$ & & \\
\hline
\end{tabular}

$\mathrm{CI}=1.043-1.090)$ and $\mathrm{SO}_{2}$ levels (adjusted $\mathrm{OR}=0.740$; $95 \% \mathrm{CI}=0.645-0.850)$.

\section{Discussion}

Birth defects are the main causes of perinatal death, missed abortion, and child disabilities and have been a global public health issue. They are generally caused by several factors. Risk factors which contribute to birth defects include genetic factors, environmental factors, chemicals and maternal elements [16]. Our study investigated the possible association between ambient air pollution and risk of birth defects. The study contributes to a growing body of epidemiologic literatures on the adverse reproductive effects of air pollution exposure. We found mixed

Table 2 Daily air pollution levels in Haikou (ppb)

\begin{tabular}{|c|c|c|c|c|c|c|c|c|}
\hline \multirow{2}{*}{$\begin{array}{l}\text { Air } \\
\text { pollutants }\end{array}$} & \multirow[t]{2}{*}{ Year } & \multirow[t]{2}{*}{$\mathbf{N}$} & \multirow[t]{2}{*}{ Mean } & \multirow[t]{2}{*}{ SD } & \multicolumn{2}{|l|}{$95 \% \mathrm{Cl}$} & \multirow[t]{2}{*}{$F$} & \multirow[t]{2}{*}{$P$} \\
\hline & & & & & Lower & Upper & & \\
\hline & 2009 & 365 & 15.88 & 4.75 & 15.39 & 16.37 & 0.638 & 0.529 \\
\hline \multirow[t]{3}{*}{$\mathrm{NO}_{2}$} & 2010 & 365 & 15.43 & 6.14 & 14.80 & 16.06 & & \\
\hline & 2011 & 365 & 15.74 & 5.60 & 15.16 & 16.32 & & \\
\hline & 2009 & 365 & 38.38 & 15.41 & 36.79 & 39.96 & 1.510 & 0.221 \\
\hline \multirow[t]{3}{*}{$\mathrm{PM}_{10}$} & 2010 & 365 & 40.17 & 21.19 & 37.99 & 42.35 & & \\
\hline & 2011 & 365 & 40.62 & 18.35 & 38.73 & 42.51 & & \\
\hline & 2009 & 365 & 7.03 & 3.91 & 6.63 & 7.43 & 9.753 & $<0.0001$ \\
\hline \multirow[t]{2}{*}{$\mathrm{SO}_{2}$} & 2010 & 365 & 6.72 & 3.58 & 6.35 & 7.09 & & \\
\hline & 2011 & 365 & 7.94 & 4.17 & 7.51 & 8.37 & & \\
\hline
\end{tabular}

$\mathrm{SD}=$ Std Deviation; $\mathrm{Cl}=$ Confidence interval. results across all analyses. In the second month of pregnancy, the risk of birth defects was related to $\mathrm{PM}_{10}$ levels (adjusted $\mathrm{OR}=1.039 ; 95 \% \mathrm{CI}=1.016-1.063$ ) and $\mathrm{SO}_{2}$ levels (adjusted OR $=0.843 ; 95 \% \mathrm{CI}=0.733-0.969$ ). In the third month of pregnancy, the risk of birth defects was also related to PM10 levels (adjusted OR $=1.066 ; 95 \%$ $\mathrm{CI}=1.043-1.090$ ) and $\mathrm{SO}_{2}$ levels (adjusted $\mathrm{OR}=0.740$; $95 \% \mathrm{CI}=0.645-0.850)$. The most susceptible time periods in pregnancy for the effects of $\mathrm{SO}_{2}$ and $\mathrm{PM}_{10}$ were the second and third month of gestation. $\mathrm{SO}_{2}$ is a major air

Table 3 OR $(95 \% \mathrm{CI})$ for birth defects during the first 3 months of pregnancy in single-pollutant model

\begin{tabular}{|c|c|c|c|c|c|c|c|}
\hline \multirow[t]{2}{*}{ Pollutants } & \multirow[t]{2}{*}{$\beta$} & \multirow[t]{2}{*}{ SE } & \multirow[t]{2}{*}{$x^{2}$} & \multirow[t]{2}{*}{$P$} & \multirow[t]{2}{*}{ OR } & \multicolumn{2}{|c|}{ OR $95 \% \mathrm{Cl}$} \\
\hline & & & & & & Lower & Upper \\
\hline \multicolumn{8}{|l|}{$\mathrm{NO}_{2}$} \\
\hline 1st month & -0.001 & 0.015 & 0.004 & 0.949 & 0.999 & 0.97 & 1.03 \\
\hline 2nd month & -0.002 & 0.015 & 0.024 & 0.876 & 0.998 & 0.968 & 1.028 \\
\hline 3rd month & -0.004 & 0.015 & 0.071 & 0.790 & 0.996 & 0.967 & 1.026 \\
\hline \multicolumn{8}{|l|}{$\mathrm{PM}_{10}$} \\
\hline 1st month & 0.008 & 0.004 & 3.113 & 0.078 & 1.008 & 0.999 & 1.017 \\
\hline 2nd month & 0.006 & 0.005 & 1.618 & 0.203 & 1.006 & 0.997 & 1.015 \\
\hline 3rd month & 0.012 & 0.005 & 6.825 & 0.009 & 1.012 & 1.003 & 1.021 \\
\hline \multicolumn{8}{|l|}{$\mathrm{SO}_{2}$} \\
\hline 1st month & 0.027 & 0.024 & 1.315 & 0.252 & 1.028 & 0.981 & 1.077 \\
\hline 2nd month & 0.025 & 0.024 & 1.063 & 0.303 & 1.025 & 0.978 & 1.075 \\
\hline 3rd month & 0.03 & 0.025 & 1.484 & 0.223 & 1.030 & 0.982 & 1.081 \\
\hline
\end{tabular}

$P<0.05$ indicates the difference was statistically significant. 
Table 4 OR $(95 \% \mathrm{Cl})$ for birth defects during the first 3 months of pregnancy in three-pollutant models

\begin{tabular}{|c|c|c|c|c|c|c|c|}
\hline \multirow[t]{2}{*}{ Pollutants } & \multirow[t]{2}{*}{$\beta$} & \multirow[t]{2}{*}{ SE } & \multirow[t]{2}{*}{$x^{2}$} & \multirow[t]{2}{*}{$P$} & \multirow[t]{2}{*}{ OR } & \multicolumn{2}{|c|}{ OR 95\% Cl } \\
\hline & & & & & & Lower & Upper \\
\hline \multicolumn{8}{|l|}{ 1st month } \\
\hline $\mathrm{NO}_{2}$ & -0.017 & 0.021 & 0.641 & 0.424 & 0.984 & 0.945 & 1.024 \\
\hline $\mathrm{PM}_{10}$ & 0.013 & 0.009 & 1.953 & 0.162 & 1.013 & 0.995 & 1.031 \\
\hline $\mathrm{SO}_{2}$ & -0.015 & 0.056 & 0.075 & 0.784 & 0.985 & 0.883 & 1.098 \\
\hline \multicolumn{8}{|l|}{ 2nd month } \\
\hline $\mathrm{NO}_{2}$ & -0.019 & 0.02 & 0.909 & 0.340 & 0.981 & 0.943 & 1.021 \\
\hline $\mathrm{PM}_{10}$ & 0.006 & 0.009 & 0.401 & 0.527 & 1.006 & 0.988 & 1.024 \\
\hline $\mathrm{SO}_{2}$ & 0.018 & 0.054 & 0.116 & 0.734 & 1.019 & 0.917 & 1.132 \\
\hline \multicolumn{8}{|l|}{ 3rd month } \\
\hline $\mathrm{NO}_{2}$ & -0.025 & 0.02 & 1.492 & 0.222 & 0.976 & 0.937 & 1.015 \\
\hline $\mathrm{PM}_{10}$ & 0.024 & 0.009 & 8.039 & 0.005 & 1.024 & 1.007 & 1.042 \\
\hline $\mathrm{SO}_{2}$ & -0.051 & 0.051 & 1.02 & 0.313 & 0.95 & 0.86 & 1.049 \\
\hline
\end{tabular}

$P<0.05$ indicates the difference was statistically significant.

pollutant produced from coal and oil combustion, which has significant impacts upon human health. Particulate matter includes a variety of pollutants that are suspended as particles in the air, such as road dust, ash and smoke.

There have been inconsistent results across previous studies that have examined associations between ambient air pollution and birth defects. And, each of these studies found only one or two associations. For example, in Brisbane, Australia, exposure to $\mathrm{PM}_{10}, \mathrm{NO}_{2}, \mathrm{SO}_{2}, \mathrm{CO}$ and $\mathrm{O}_{3}$ was examined and results showed that $\mathrm{O}_{3}$ was associated with an increased risk of aortic artery and valve defects and $\mathrm{SO}_{2}$ was associated with cleft lip with or without cleft palate [10]. The study conducted in Atlanta, Georgia, examined 12 types of cardiovascular

Table 5 Adjusted OR (95\% Cl) for birth defects during the first 3 months of pregnancy in single-pollutant model

\begin{tabular}{|c|c|c|c|c|c|c|c|}
\hline \multirow[t]{2}{*}{ Pollutants } & \multirow[t]{2}{*}{$\beta$} & \multirow[t]{2}{*}{ SE } & \multirow[t]{2}{*}{$x^{2}$} & \multirow[t]{2}{*}{$P$} & \multirow[t]{2}{*}{ OR } & \multicolumn{2}{|c|}{ OR $95 \% \mathrm{Cl}$} \\
\hline & & & & & & Lower & Upper \\
\hline \multicolumn{8}{|l|}{$\mathrm{NO}_{2}$} \\
\hline 1st month & 0.015 & 0.021 & 0.529 & 0.467 & 1.015 & 0.975 & 1.058 \\
\hline 2nd month & -0.003 & 0.021 & 0.024 & 0.876 & 0.997 & 0.956 & 1.039 \\
\hline 3rd month & -0.001 & 0.022 & 0.004 & 0.949 & 0.999 & 0.957 & 1.042 \\
\hline \multicolumn{8}{|l|}{$\mathrm{PM}_{10}$} \\
\hline 1st month & 0.005 & 0.006 & 0.54 & 0.463 & 1.005 & 0.993 & 1.017 \\
\hline 2nd month & 0.012 & 0.006 & 3.85 & 0.050 & 1.012 & 1.000 & 1.025 \\
\hline 3rd month & 0.021 & 0.006 & 10.368 & 0.001 & 1.021 & 1.008 & 1.034 \\
\hline \multicolumn{8}{|l|}{$\mathrm{SO}_{2}$} \\
\hline 1st month & -0.003 & 0.034 & 0.006 & 0.938 & 0.997 & 0.934 & 1.066 \\
\hline 2nd month & 0.005 & 0.035 & 0.018 & 0.895 & 1.005 & 0.938 & 1.076 \\
\hline 3rd month & -0.005 & 0.036 & 0.022 & 0.882 & 0.995 & 0.928 & 1.066 \\
\hline
\end{tabular}

$P<0.05$ indicates the difference was statistically significant.
Table 6 Adjusted OR (95\% Cl) for birth defects during the first 3 months of pregnancy in three-pollutant models

\begin{tabular}{|c|c|c|c|c|c|c|c|}
\hline \multirow[t]{2}{*}{ Pollutants } & \multirow[t]{2}{*}{$\beta$} & \multirow[t]{2}{*}{ SE } & \multirow[t]{2}{*}{$x^{2}$} & \multirow[t]{2}{*}{$P$} & \multirow[t]{2}{*}{ OR } & \multicolumn{2}{|c|}{ OR $95 \% \mathrm{Cl}$} \\
\hline & & & & & & Lower & Upper \\
\hline \multicolumn{8}{|l|}{ 1st month } \\
\hline $\mathrm{NO}_{2}$ & 0.033 & 0.027 & 1.446 & 0.229 & 1.033 & 0.98 & 1.09 \\
\hline $\mathrm{PM}_{10}$ & 0.020 & 0.012 & 2.807 & 0.094 & 1.020 & 0.997 & 1.045 \\
\hline $\mathrm{SO}_{2}$ & -0.130 & 0.074 & 3.115 & 0.078 & 0.878 & 0.76 & 1.015 \\
\hline \multicolumn{8}{|l|}{ 2nd month } \\
\hline $\mathrm{NO}_{2}$ & 0.001 & 0.027 & 0.002 & 0.964 & 1.001 & 0.949 & 1.056 \\
\hline $\mathrm{PM}_{10}$ & 0.038 & 0.012 & 10.995 & 0.001 & 1.039 & 1.016 & 1.063 \\
\hline $\mathrm{SO}_{2}$ & -0.171 & 0.071 & 5.786 & 0.016 & 0.843 & 0.733 & 0.969 \\
\hline \multicolumn{8}{|l|}{ 3rd month } \\
\hline $\mathrm{NO}_{2}$ & 0.008 & 0.028 & 0.088 & 0.767 & 1.008 & 0.954 & 1.066 \\
\hline $\mathrm{PM}_{10}$ & 0.064 & 0.011 & 32.092 & $<0.001$ & 1.066 & 1.043 & 1.090 \\
\hline $\mathrm{SO}_{2}$ & -0.301 & 0.07 & 18.386 & $<0.001$ & 0.740 & 0.645 & 0.850 \\
\hline
\end{tabular}

$P<0.05$ indicates the difference was statistically significant.

malformations and five pollutants $\left(\mathrm{CO}, \mathrm{NO}_{2}, \mathrm{PM}_{10}, \mathrm{SO}_{2}\right.$, and $\mathrm{O}_{3}$ ) and found a statistically significant association between $\mathrm{PM}_{10}$ and patent ductus arteriosus [17]. The results from the Texas study revealed that the positive associations between $\mathrm{CO}$ and Tetralogy of Fallot, $\mathrm{PM}_{10}$ and atrial septal defect, and $\mathrm{SO}_{2}$ and ventricular septal defect [18]. In South California, exposure to ambient $\mathrm{PM}_{10}, \mathrm{NO}_{2}, \mathrm{O}_{3}$ and $\mathrm{CO}$ during each of the first three months of pregnancy was examined and the results only showed the association between $\mathrm{CO}$ and increased risk of cardiac ventricular septal defects, $\mathrm{O}_{3}$ and an increased risk of aortic artery and valve defects [9].

Compared with previous studies, one potentially important difference is that we estimated the effect of air pollution as categorical exposure, whereas other studies estimated the effect of air pollution as continuous exposure $[17,19]$. Using a categorical exposure puts no restrictions on the shape of the exposure-risk relationship, but reduces statistical power.

Previous studies have shown that maternal exposure to air pollutants can have teratogenic effects. Possible mechanisms of air pollutants on birth defect remain speculative. Air pollutants might be involved in the development of skeletal malformation via hemodynamic, anoxic events, oxidative stress, and toxicity to certain cell populations during pregnancy [9].

In our study, we observed an increased risk of birth defects for second-month and third-month $\mathrm{PM}_{10}$ exposures. Thus, the timing of $\mathrm{PM}_{10}$ exposure is consistent with embryo development. However, we also found a reduced risk associated with increased $\mathrm{SO}_{2}$ exposures in the second and third month, which might suggest these fetuses are vulnerable when exposed to $\mathrm{SO}_{2}$. We can not rule out ascertainment bias due to prenatal diagnosis as 
well as selective abortion of fetuses with birth defects. This observation on $\mathrm{PM}_{10}$ and $\mathrm{SO}_{2}$ might suggest that a different effect of air pollutants on birth defects.

Our study had several strengths. We conducted a large, population-based analysis using a high-quality birth defects monitoring network with air pollution monitoring data from Haikou Environmental Monitoring Center. To allow adjustment for the possible effect of weather on birth defects, some meteorologic factors, such as daily average temperature, humidity data were collected from Haikou Meteorological Bureau. We adjusted for several confounders in the logistic regression analysis to eliminate the factors as a potential explanation for our results. Our study used a large number of birth records based on birth certificates, which reduces uncertainties due to selection bias which is more common in smaller studies. Despite these efforts, however, residual confounding is possible. First, the monitoring period was 28 weeks' gestation to 6 days after delivery, and babies with birth defect detected more than 7 days after delivery would be missed. And we can not study the effect of air pollution on infants with birth defect more than 7 days after delivery. Second, we assigned concentrations of air pollutants from the monitoring sites to all women residing in a large area rather than measuring each pregnant woman's exposure to each pollutant during pregnancy. Second, several factors including maternal smoking, occupational exposures, and vitamin supplement use might be potential risk factors for birth defect. We were unable to evaluate, because they are not adequately reported on Haikou birth certificates.

\section{Conclusion}

Our study contributes to a growing body of epidemiologic literature on the adverse reproductive effects of air pollution exposure. Our results suggest that exposure to $\mathrm{PM}_{10}$ during the second and third month of pregnancy may contribute to the occurrence of birth defects. To date, a limited body of evidence has linked maternal exposure to ambient $\mathrm{SO}_{2}, \mathrm{NO}_{2}$ and $\mathrm{PM}_{10}$ to the occurrence of birth defect. Further studies are needed to address these associations.

\section{Competing interests}

The authors declare that they have no competing interests.

\section{Authors' contributions}

$\mathrm{ZL}$ participated in the design of the study and performed the statistical analysis. LW drafted the manuscript. LF assisted in data management and analyses. QZ contributed in the study design and manuscript editing. All authors read and approved the final manuscript.

\section{Acknowledgements}

The authors are grateful to all of the participants who kindly participated in this study.

\section{Author details}

${ }^{1}$ Guangdong Women and Children Hospital, Guangzhou, China. ${ }^{2}$ Hainan

Women and Children Hospital, Haikou, China.
Received: 11 June 2014 Accepted: 20 October 2014

Published online: 22 November 2014

\section{References}

1. Mainolfi MB, Salihu HM, Wilson RE, Mbah AK: Low-level exposure to air pollution and risk of adverse birth outcomes in Hillsborough County, Florida. J Occup Environ Med 2013, 55(5):490-494.

2. Laumbach RJ: Outdoor air pollutants and patient health. Am Fam Physician 2010, 81(2):175-180

3. Bobak M: Outdoor air pollution, low birth weight, and prematurity. Environ Health Perspect 2000, 108(2):173-176.

4. Rich DQ, Demissie K, Lu SE, Kamat L, Wartenberg D, Rhoads GG: Ambient air pollutant concentrations during pregnancy and the risk of fetal growth restriction. J Epidemiol Community Health 2009, 63(6):488-496

5. Sram RJ, Binkova B, Dejmek J, Bobak M: Ambient air pollution and pregnancy outcomes: a review of the literature. Environ Health Perspect 2005, 113(4):375-382.

6. Wilhelm M, Ritz B: Residential proximity to traffic and adverse birth outcomes in Los Angeles county, California, 1994-1996. Environ Health Perspect 2003, 111(2):207-216.

7. Zhao Q, Liang Z, Tao S, Zhu J, Du Y: Effects of air pollution on neonatal prematurity in Guangzhou of China: a time-series study. Environ Health 2011, 10:2.

8. Smrcka V, Leznarova D: Environmental pollution and the occurrence of congenital defects in a 15-year period in a south Moravian district. Acta Chir Plast 1998, 40(4):112-114.

9. Ritz B, Yu F, Fruin S, Chapa G, Shaw GM, Harris JA: Ambient air pollution and risk of birth defects in Southern California. Am J Epidemiol 2002, 155(1):17-25.

10. Hansen $C A$, Barnett AG, Jalaludin BB, Morgan GG: Ambient air pollution and birth defects in Brisbane, Australia. PLoS One 2009, 4(4):e5408.

11. Christianson A, Howson C, Modell B: March of dimes global report on birth defects. White Plains, New York: March or Dimes Foundation, http://www.marchofdimes.com/downloads/Birth_Defects_Report-PF.pdf (accessed October 19, 2010); 2006.

12. Ministry of Health of China CDPF: China action to improve constitution of birth population quality and reduce birth defects and disabilities (2002-2010). Zhongguo Sheng Yu Jian Kang Za Zhi 2002, 13:98-101.

13. Dai L, Zhou G, Zhu J, Miao L, Wang Y, Wu Y, Liang J, Mao M: Impacts of birth defects on perinatal deaths in Chinese population. Zhonghua Liu Xing Bing Xue Za Zhi 2004, 25:138-141.

14. Seller M: Genetic causes of congential anomalies and their interaction with envirmmental factors. EUROCAT Special Report The environmental causes of congenital anomalies: a review of the literature. (Available at: www.eurocat.ulster.ac.uk/pubdata Accessed: 10 December 2008); 2004

15. Wyszynski DF, Wu T: Prenatal and perinatal factors associated with isolated oral clefting. Cleft Palate Craniofac J 2002, 39(3):370-375.

16. Wilson J: Handbook of Teratology(Wilson JG \& Frasor Foeds). In Embryo toxicity of drugs in man. New York: Plenum; 1997.

17. Strickland MJ, Klein M, Correa A, Reller MD, Mahle WT, Riehle-Colarusso TJ, Botto LD, Flanders WD, Mulholland JA, Siffel C, Marcus M, Tolbert PE: Ambient air pollution and cardiovascular malformations in Atlanta, Georgia, 1986-2003. Am J Epidemiol 2009, 169(8):1004-1014.

18. Gilboa SM, Mendola P, Olshan AF, Langlois PH, Savitz DA, Loomis D, Herring AH, Fixler DE: Relation between ambient air quality and selected birth defects, seven county study, Texas, 1997-2000. Am J Epidemiol 2005, 162(3):238-252.

19. Hwang BF, Jaakkola JJ: Ozone and other air pollutants and the risk of oral clefts. Environ Health Perspect 2008, 116(10):1411-1415.

doi:10.1186/s12887-014-0283-6

Cite this article as: Liang et al:: Ambient air pollution and birth defects in Haikou city, Hainan province. BMC Pediatrics 2014 14:283. 